\title{
The Effect of Visible Light Cure (VLC) Exposure to Gingival Tissue's Sprague dawley Rats
}

\author{
Kwartarini Murdiastuti \\ Suryono \\ Aini Moeljono \\ Mefi Priba Sari \\ Rani Gamawati \\ Department of Periodontology, Faculty of Dentistry, \\ Universitas Gadjah Mada, Yogyakarta, Indonesia \\ E-mail:kmurdiastuti@yahoo.com \\ Received August 15, 2010; Accepted December 10, 2010
}

\begin{abstract}
Visible Light Cure (VLC) is a blue light used in dentistry as an activator for restorative material and fixed orthodontic bonding. The wavelength of VLC is between 400-500 nm and considered non-ionizing radiation that can produce free radicals. According to previous research, the light at wavelength $<500 \mathrm{~nm}$ could inhibit cells mitosis, cause cells damage, and reduce cells growth and inflammation. The purpose of this study was to investigate the effect of VLC exposure on gingival epithelial thickness, total neutrophil and macrophage count of gingival connective tissue of Sprague dawley rats. The subjects of this study consisted of 20 Sprague dawley rats, in 2-3 months of age and divided into 4 groups. Each group was 5 rats. The rats in each group were sacrificed before ( 0 day, as group A) and after $1^{\text {st }}$ (group B), $3^{\text {rd }}$ (group C), $5^{\text {th }}$ (group D) day of VLC exposure, respectively. The exposure of VLC was done in labial aspect of cervical anterior teeth of mandible. The distance of exposure was as thick as 2 layers of celluloid strip and the histological specimens were stained by Hematoxylin Eosin. Each specimen was measured for its gingival epithelial thickness by using a micrometer and the number of neutrophil and macrophage were counted. The data of gingival epithelial thickness from 4 groups were analyzed by Kruskal Wallis. The number of neutrophil and macrophage were analyzed by using one way ANOVA. The results of this study showed that there were significant differences among groups on the thickness of gingival epithelial, the number of neutrophil and macrophage in the gingival connective tissue of Sprague dawley rats. The result of this study indicated that VLC exposure might decrease the thickness of gingival epithelial but increase the number of neutrophil and macrophage of gingival connective tissue of Sprague dawley rats.
\end{abstract}

Keywords: Visible Light Cure, radiation, epithelial thickness, neutrophil, macrophage.

\section{Introduction}

In dentistry curing unit is commonly used when restoring teeth using composite resin materials. The device produces Visible Light Cure (VLC) to initiate the polymerization of composite resin. Visible Light
Cure is a light with $400-500 \mathrm{~nm}$ wavelength in the blue region of the visible light spectrum ${ }^{1}$.

Based on its wave length, VLC belongs to nonionizing radiation which is classified into optical radiation. Radiation exposure can cause damage at the level of molecules, cells, tissues, or organs. 
Radiation induces cell damage and even death due to the mechanism of cell mitosis disturbance ${ }^{2}$.

Nowadays the use of composite resin polymerized by visible light is getting more popular, as well as replacing composite resin polymerized by chemical agent or ultra violet. Along with that condition, the current dental practices have been using VLC ${ }^{3}$. Meanwhile, Alatas and Lusiyanti stated that visible blue light exposure $(400-550 \mathrm{~nm})$ can induce retinal damage, known as blue-light retinal injury ${ }^{2}$.

Gingiva is one of periodontal tissues that surrounding the teeth and alveolar bone and expanding to mucogingival. This structure attaches to the teeth and alveolar bone. The function of gingiva is to protect the subgingival tissue from oral cavity environment. Histologically, gingiva consists of gingival epithelial layers and gingival connective tissue ${ }^{4}$. Blood vessel supplies of gingival connective tissue are formed by arterioles plexus, capillaries, and small veins that extend from the sulcular epithelial toward the outer surface of the gingiva ${ }^{5}$.

The uses of VLC in dental practice may influence the gingival tissue. VLC exposure can cause cell damage and reduce cell growth. In this case, the gingival epithelial cells exposed by VLC possibly undergo structural alteration.

Radiation of VLC exposure causes acute inflammation ${ }^{6}$. Inflammation is an essential process that is critical to host defense. Meanwhile, acute inflammation implies an inflammatory reaction that develops over a rapid time scale (hours to days). Acute inflammation can provide a clean-up function that segues to tissue repair ${ }^{7}$. Acute inflammation response includes the process of vascular changes and blood flow, capillary permeability increases, and formation of cellular components through the migration of leukocytes into the extravascular tissues $^{8}$. Only two types of leukocytes involve in acute inflammation those are neutrophil and macrophage ${ }^{9}$.

The purpose of this study was to investigate the effect of VLC exposure on gingival epithelial thickness, total neutrophil and macrophage count of gingival connective tissue of Sprague dawley rats.

\section{Materials and Methods}

The subjects of this study were 20 Sprague dawley rats, 2-3 months of age, which were divided into 4 groups. Rats in group A were sacrificed before VLC exposure (day 0 ), while in group $B, C$ and $D$, rats were sacrificed on $1^{\text {st }}, 3^{\text {rd }}$ and $5^{\text {th }}$ day after VLC exposure respectively. The exposure of VLC was done for 30 seconds and the distance was as thick as 2 layers of celluloid strip from labial cervical of mandible anterior teeth.

Histological specimens were stained with Hematoxylin Eosin and observed using 400x magnification of light microscope. The thickness of gingival epithelial was measured using a micrometer from the basal to the cornified layer in 10 fields of view for each specimen. For the number of neutrophil and macrophage, specimens were observed in 10 fields of view as well. The average thickness of gingival epithelial was analyzed by Kruskal Wallis and Mann-Whitney test. However the average number of neutrophil and macrophage were analyzed by one way ANOVA.

\section{Results}

The highest average of gingival epithelial thickness $(80.5 \mu \mathrm{m})$ and the average of neutrophil and macrophage numbers (2.8 and 1.8, respectively) were found before VLC exposure as shown in Figure 1.

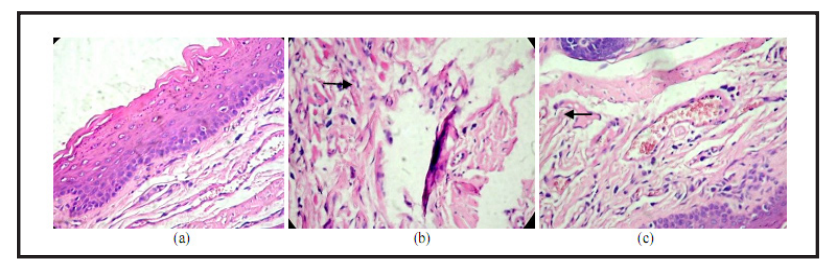

Figure 1. Hematoxylin Eosin staining of the gingival tissue of Sprague dawley rats in group A, before VLC exposure ( 0 day), (a) The thickness of gingival epithelial; (b) the number of neutrophil (arrows); (c) the number of macrophage (arrows) (400x Magnification). 
Figure 2 shows histological specimens at $1^{\text {st }}$ day after VLC exposure. A decrease on average of gingival epithelial thickness to be $77.7 \mu \mathrm{m}$ was found. Meanwhile, the average of neutrophil and macrophage number increased to 11.8 and 2.2 respectively. Decrease of gingival epithelial thickness average to $76.4 \mu \mathrm{m}$ was found $3^{\text {rd }}$ day after VLC exposure as shown in Figure 3. However the average of neutrophil number decreased to 7.00 , whereas the average of macrophage number increased to 6.2.

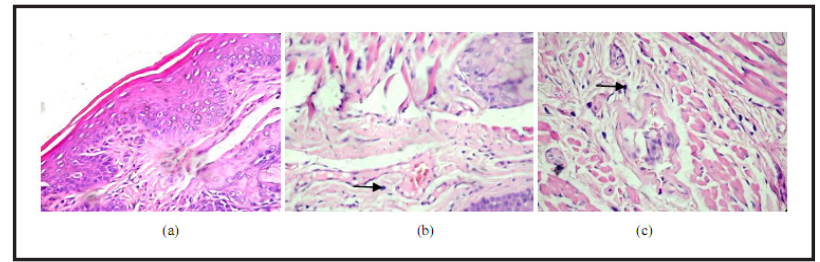

Figure 2. Hematoxylin Eosin staining of the gingival tissue of Sprague dawley rats in the group B, the $1^{\text {st }}$ day after VLC exposure, (a) the thickness of gingival epithelial; (b) the number of neutrophil (arrows); (c) the number of macrophage (arrows) (400x Magnification).

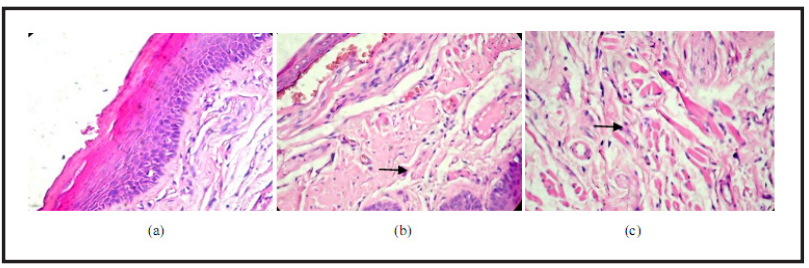

Figure 3. Hematoxylin Eosin staining of the gingival tissue's Sprague dawley rats in the group $\mathrm{C}$, the $3^{\text {rd }}$ day after VLC exposure, (a) the thickness of gingival epithelial; (b) the number of neutrophil (arrows); (c) the number of macrophage (arrows) (400x Magnification).

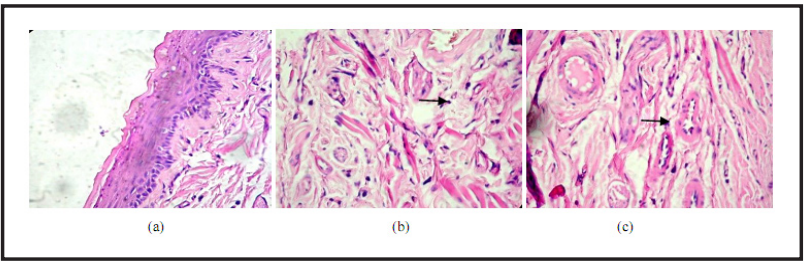

Figure 4. Hematoxylin Eosin staining of the gingival tissue's Sprague dawley rats in the group D, the $5^{\text {th }}$ day after VLC exposure, (a) the thickness of gingival epithelial; (b) the number of neutrophil (arrows); (c) the number of macrophage (arrows) (400x Magnification).
The lowest average of gingival epithelial thickness of $72.95 \mu \mathrm{m}$ was found at $5^{\text {th }}$ day after VLC exposure, shown in Figure 4. In the other hand, the average of neutrophil number was not different from $3^{\text {rd }}$ to $5^{\text {th }}$ day after VLC exposure. However the average of macrophage number declined by 2.4 .

Table 1. Mean and standard deviation of gingival epithelial thickness, neutrophil and macrophage number in gingival tissue's Sprague dawley rats.

\begin{tabular}{cccc}
\hline Group & $\begin{array}{c}\text { Epithelial } \\
\text { thickness } \\
(\mu \mathrm{m})\end{array}$ & $\begin{array}{c}\text { Neutrophil } \\
\text { number }\end{array}$ & $\begin{array}{c}\text { Macro- } \\
\text { phage } \\
\text { number }\end{array}$ \\
\hline 0 day (A) & $80.50 \pm 1.94$ & $2.80 \pm 0.84$ & $1.8 \pm 0.84$ \\
$1^{\text {st }}$ day (B) & $77.70 \pm 0.54$ & $11.8 \pm 3.11$ & $2.2 \pm 0.84$ \\
$3^{\text {rd }}$ day (C) & $76.40 \pm 0.60$ & $7.00 \pm 1.58$ & $6.2 \pm 0.84$ \\
$5^{\text {th }}$ day (D) & $72.95 \pm 1.08$ & $2.80 \pm 1.30$ & $2.4 \pm 1.14$ \\
\hline
\end{tabular}

Figure 5 showed increasing gingival epithelial thickness from 0 to $5^{\text {th }}$ day after VLC exposure. The average differences between groups $B$ and $C$ was $1.3 \mu \mathrm{m}$, and group $C$ to $D$ was $3.45 \mu \mathrm{m}$. Data on the thickness of epithelial gingival was not homogeneously distributed, thus Kruskal Wallis test was conducted and the results showed $p=0.001$. It means VLC exposure effected epithelial thickness $(p<0.05)$.

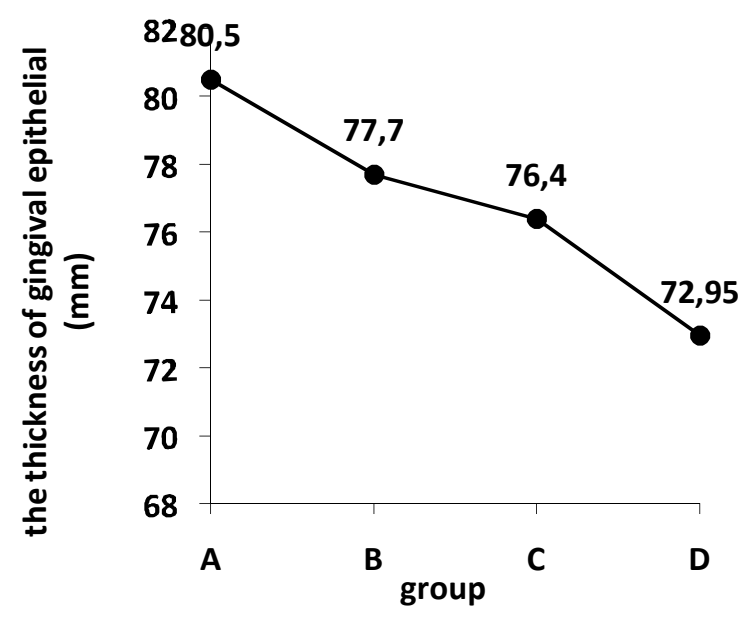

Figure 5. The thickness of gingival epithelial Sprague dawley rats in each group. 


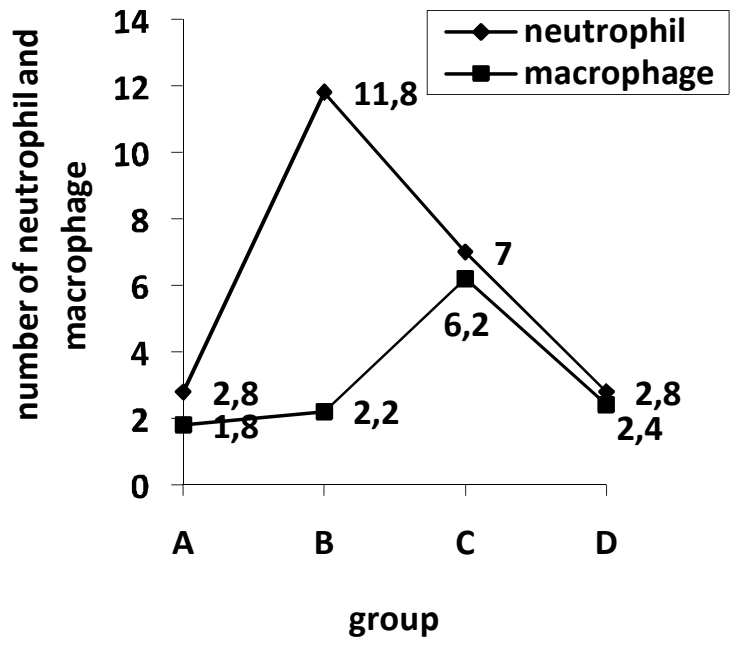

Figure 6. The number of neutrophil and macrophage of gingival connective tissue of Sprague dawley rats in each group.

Fluctuation on neutrophil and macrophage number from 0 to $5^{\text {th }}$ day is shown in Figure 6 . After increasing from 0 to $1^{\text {st }}$ day, neutrophil number decreased up to $5^{\text {th }}$ day. Observation on macrophage number showed increasing results from 0 to $3^{\text {rd }}$ day and decreasing until $5^{\text {th }}$ day. One way ANOVA test was applied on neutrophil and macrophage number of connective tissue of Sprague dawley rat. One way ANOVA test results in Table II and III showed $p<0.05$, thus demonstrated significant differences among groups on the average of neutrophil and macrophage number upon VLC exposure on gingival connective tissue Sprague dawley rats, respectively.

Table 2. One Way ANOVA results on neutrophil number of gingival connective tissue of Sprague dawley rats.

\begin{tabular}{lccccc}
\hline Source & $\begin{array}{c}\text { Sum of } \\
\text { Squares }\end{array}$ & df & $\begin{array}{c}\text { Mean } \\
\text { Square }\end{array}$ & F ratio & sig. \\
\hline $\begin{array}{l}\text { Between } \\
\text { groups }\end{array}$ & 275.400 & 3 & 91.800 & 25.151 & .000 \\
$\begin{array}{l}\text { Within } \\
\text { groups }\end{array}$ & 58.400 & 16 & 3.650 & & \\
Total & 333.800 & 19 & & & \\
\hline
\end{tabular}

df: degree of freedom; sig.: significance.
Table 3. One Way ANOVA results on macrophage number of gingival connective tissue of Sprague dawley rats.

\begin{tabular}{lrrrrr}
\hline Source & $\begin{array}{l}\text { Sum of } \\
\text { Squares }\end{array}$ & df & $\begin{array}{c}\text { Mean } \\
\text { Square }\end{array}$ & $\begin{array}{c}\text { F } \\
\text { ratio }\end{array}$ & sig. \\
\hline $\begin{array}{l}\text { Between } \\
\text { groups }\end{array}$ & 62.950 & 3 & 20.983 & 24.686 & .000 \\
$\begin{array}{l}\text { Within } \\
\text { groups }\end{array}$ & 13.600 & 16 & .850 & & \\
Total & 76.550 & 19 & & & \\
\hline
\end{tabular}

df: degree of freedom; sig.: significance.

\section{Discussion}

Visible Light Cure (VLC), a blue light with a wavelength between $400-500 \mathrm{~nm}^{1}$, can be classified as visible light radiation or non-ionizing radiation ${ }^{2}$. It can cause thermal and photochemical reactions ${ }^{10}$. This study results showed that VLC not only decreases the average of epithelial gingival thickness but also increases the average of neutrophil and macrophage number. Those were presumably because VLC exposure interfere the epithelial cell itself and the process of turnover.

Disruption of epithelial cells by VLC exposure occurs in mitocondria, which is the center of the cell metabolism. Cell metabolism requires factor of electron carriers, such as flavins and cytochrom ${ }^{11}$. Visible LightCureabsorbed by flavins causes decreasing SDH (succinic dehydrogenase) activity ${ }^{10}$. Succinic dehydrogenase is oxidation catalyze of fumarat in the Kreb's cycle. Succinic dehydrogenase disturbance decreases the production of ATP which is the energy for cell metabolism. Visible light cure absorbed by cytochrome forms excess of Reactive Oxygen Species $(\mathrm{ROS})^{12}$. However, ROS is a molecule with free valence electrons that can cause cell damage ${ }^{13}$.

In response to tissue damage, acute inflammation reaction will occur in early stages of inflammation such as capillary vasodilation and increasing blood flow and capillary permeability ${ }^{14}$. This process is stimulated by inflamatory mediators, such as histamin, serotonin, leukotrien, bradikinin, and prostaglandin ${ }^{4}$. 
After blood flow decreases, leucocytes move closer to the vessel wall. Begins with neutrophil then monocytes move aside and adhere to the wall. This will be followed by an active amuboid movement of the cells into perivascular tissue through gaps betweenendothelialcells. Afterneutrophilextravatation, monocytes differentiate into macrophages and move toward areas of inflammation in a chemotatic way, thus accumulation of neutrophil followed by macrophage in the tissue can be observed ${ }^{15}$.

This study showed decreasing average of gingival epithelial thickness from $1^{\text {st }}$ to $5^{\text {th }}$ day which apparently caused by mitosis disruption in basal lamina. Based on the previous study, the turnover of rat gingival epithelial is 6-8 days ${ }^{7}$. Cells of basal layer take 4-6 days to move towards spinous and granular layer. In next 2 days, the cells move to cornified layer ${ }^{7}$. Decrease on gingival epithelial thickness average between $1^{\text {st }}$ to $3^{\text {rd }}$ day was smaller than $3^{\text {rd }}$ to $5^{\text {th }}$ day. This possibly because at $3^{\text {rd }}$ day, epithelial cells were still in basal layer, while at $5^{\text {th }}$ day epithelial cells were in spinous layer. In this layer, epithelial cells is observed in its largest size. Exposure of VLC disrupts cells mitosis and leads to decrease on cell production. Reducing number of cells causes decrease on epithelial thickness. When cells enter movement phase towards spinous layer, decreasing on epithelial thickness become obviously observed.

This study showed on the $1^{\text {st }}$ day after VLC exposure, average of neutrophil number was highly increased. The results is in accordance with Kumar et al. (1997) that neutrophil domination is observed at 6-24 hours after exposure ${ }^{16}$. However, the average of neutrophil number was then subsequently decreasing until $5^{\text {th }}$ day. This finding is in agreement with Junquiera and Carneiro (2007) that the neutrophil has a lifespan of over one to four days in the connective tissue and finally died after its mission ${ }^{9}$. In this study, most of neutrophil are presumably completed the mission and died at $5^{\text {th }}$ day. Consequently, average number of neutrophil at $5^{\text {th }}$ day returned as before VLC exposure.

Small increase on average of macrophage number before and 1 day after VLC exposure observed in this study is presumably because not all the monocytes from the blood vessel are mature and differentiating into macrophage in tissue. Study on literature reveals that monocytes are circulating in the blood 1-2 days and less motile ${ }^{15,17}$.

In this study, average of macrophage number was notably increased between $1^{\text {st }}$ to $3^{\text {rd }}$ day. It was probably due to maturation and differentation of all monocytes into macrophage to perform phagocytosis. Phagocytosis is the main function of macrophage, including process of particles adherence on the surface of phagocytes, digestion, and eradication of damaged cells ${ }^{16}$.

The highest average of macrophage number in this study was found at $3^{\text {rd }}$ day. This is in accordance with Harrison and Jurosky (1991). They suggested that macrophage is predominantly found in inflammatory tissue on the $3^{\text {rd }}$ day $^{8}$.

However, decreasing average of macrophage number was observed between $3^{\text {rd }}$ to $5^{\text {th }}$ day in this study and indicated completion phase and beginning phase of proliferative inflammation. Kumar et al. (1997) suggested the proliferation phase occurs after 2-5 days after injury ${ }^{16}$. After phagosytosis, most of macrophage dead then gradually experience autolisis and absorbed into the surrounding tissue ${ }^{6}$. Midwood et al. (2004) stated that reduction on macrophage number possibly happens in order to avoid inflammatory processes that are too long, which in the other hand can induce tissue damage ${ }^{18}$.

The results of this study indicated that VLC exposure may decrease the thickness of gingival epithelial and increase the number of neutrophil and macrophage of gingival connective tissue of Sprague dawley rats.

\section{References}

1. Alatas Z. 2007. Efek Kesehatan Pajanan Radiasi Dosis Rendah. Cermin Dunia Kedokteran 154: $17-23$.

2. Alatas Z, Lusiyanti Y. 2003. Efek Kesehatan Radiasi Non Pengion pada Manusia. Cermin Dunia Kedokteran 138 : 34 -40.

3. Anusavice KJ. 1996. IImu Bahan Kedokteran Gigi. 10 ${ }^{\text {th }}$ Ed. EGC, Jakarta: 232-236. 
4. Fedi PF, Vernino AR, Gray JL. 2004. Silabus Periodonti. $4^{\text {th }}$ Ed. EGC. Jakarta.

5. Newman MG, Takei HH, Klokkevold PR, Carranza FA. 2006. Carranza's Clinical Periodontology, $10^{\text {th }} \mathrm{Ed}$. Saunders Co., Los Angeles.

6. Guyton A.C and Hall J.E. 1997. Buku Ajar Fisiologi Kedokteran. $9^{\text {th }}$ Ed. EGC, Jakarta: 543.

7. Hamilton IA and Blackwood HJJ. 1974. Cell Renewal of Oral Mucosal Epithelial of Rat. Journal Anatomi 117 (2): 313-27.

8. Harrison JW and Jurosky KA. 1991. Healing of Surgical Wounds in Oral Mucoperiosteal Tissues. Journal of Endodontics 17 (9): 425-435.

9. Junquiera L.C and Carneiro J. 2007. Histologi Dasar: Text and Atlas. 10th Ed. EGC. Jakarta: 236-8.

10. Wataha JC, Lockwood PE, Lewis JB, Rueggeber FA, Messer RLW. 2004 . Biological effects of blue light from dental cure units, Dental Materials Journal 20: 150-7.

11. Willey JM, Sherwod LM, and Woollverton CJ. 2009. Prescott's Principles of Microbiology. Mc Graw Hill Higher Education, Boston: 174.
12. Voskanyan KS. 2009. UV and Visible LightInduced Mutation in Eschericia Coli, http:// www.photobiology.com/photobiology99/ contrib/karin/index.html . Downloaded July 7th, 2010.

13. Wiseman $\mathrm{H}$ and Halliwell B. 1996. Damage to DNA by Reactive Oxygen and Nitrogen Species: Role in Inflamatory Disease and Progression to Cancer, Biochem Journal 313: 17-29.

14. Underwood JCE. 2000. General and Systematic Pathology. $3^{\text {rd }}$ Ed. Churchill Livingstone. London: 202-14.

15. Lawler W, Ahmed A, Hume WJ. 1992. Buku Pintar Patologi untuk Kedokteran Gigi. EGC. Jakarta: 9-11.

16. Kumar V, Ramzi SC, Stanley LR. 1997. Basic Pathology. W.B. Saunders Company. Philadelphia: 26-40.

17. Roeslan BO. 2002. Imunologi Oral. Faculty of Dentistry-Universitas Indonesia. Jakarta: 5, 38.

18. Midwood KS, Williams LV, and Schwarzbauer JE. 2004. Tissue Repair and te Dynamics of the Extracellular Matrix. The International Journal of Biochemistry and Cell Biology 36 (6): 1031-7. 